\title{
Correspondence
}

\section{Enforcement of Foreign Awards among the Silk Road Countries: With Special References to Iran and China}

\author{
Arash Izadi ${ }^{*}$
}

\section{Introduction}

The 'Silk Road' is a network of ancient overland trade routes that extended across the Asian continent connecting China to the Mediterranean Sea. ${ }^{1}$ It has existed for thousands of years, passing through many different empires, kingdoms, reigns and societies throughout history. The 'Silk Road' has further enriched the countries it passed through, transporting cultures, religions, languages and of course material goods into societies across Europe, Asia and Africa, thereby uniting them all with a common thread of cultural heritage and plural identities. ${ }^{2}$ Originally, the term 'Silk Road' was invented by German geographer, Ferdinand von Richthofen in 1877 noticing that China's silk was the major trade product. ${ }^{3}$

Today, there are over 40 countries alongside the Silk Roads. ${ }^{4}$ People in these countries have been interacting with each other involving commerce, especially trading in goods. Some of these interactions inevitably led to disputes including wars. ${ }^{5}$ It must have become clear to at least some of these early traders and diplomats that a regular mechanism for dispute resolution would be useful. ${ }^{6}$ Recent evidence further indicates that international arbitration has received widespread endorsement from scholars and commentators as a preferred method of resolving the conflicts, which often arise between the parties in commercial transaction, ${ }^{7}$ especially when the parties have diverse nationality and cultural background. That is why they need to choose a neutral, just, confidential,

* Attorney-at-Law \& Legal Consultant; Arbitrator; Post-Doctorate Researcher of Shanghai Jiao Tong University Koguan Law School. Ph.D. (Xiamen). The author may be contacted at: arash. izadi@situ.edu.cn 
organized, and cost effective means of resolving their commercial disputes. ${ }^{8}$

At the end of the arbitral process, arbitrators generally render an award, like a judgment of a national court, disposes of the parties' respective claims. Even anecdotal evidence appears that currently the vast majority of international arbitration awards are complied voluntarily, ${ }^{9}$ so that they would not require judicial enforcement, ${ }^{10}$ presumably due to the availability of enforcement mechanisms or negative publicity which would result from non-compliance. ${ }^{11}$ Nevertheless, in fact, an unsuccessful party may avoid the execution of the award, ${ }^{12}$ although the success of international arbitration depends on the ability to enforce it universally. Only if an award can be practically enforced, damages will be recovered and awarded. ${ }^{13}$ In addition, successful respondents can avoid new litigation on previously arbitrated claims by frustrated claimants only if awards are recognized. ${ }^{14}$ Therefore, judicial enforcement of the awards is crucial unless voluntary compliance exists between the relevant parties.

Ultimately, the enforceable awards play a vital role in guaranteeing parties' investment success overseas. To acquire the enforceable awards, it is then essential for foreign lawyers to familiarize themselves with the laws and regulations in relevant countries. The primary purpose of this essay is to analyze the enforcement of the awards under the New York Convention alongside the Silk Road countries from a comparative legal perspective. Here, we especially refer to China and Iran mainly because of their strategic locations as the starting point and the terminus linking other Silk Road countries. Originally, Iran and China began building the Silk Road to facilitate transactions among countries. As Iran has been bridge to the West for the Chinese, their mutual relations have been recognized as a good model for the other Silk Road countries.

This piece is composed of four parts including Introduction and Conclusion. Part two will discuss the enforceability of international awards under the New York Convention because its major role is to deliver uniform legislative standards for the court recognition and enforcement of foreign and non-domestic awards. ${ }^{15}$ Part three will carry out case studies of enforcement of the awards in China and Iran, respectively.

\section{Enforceability of Foreign Awards under the New York Convention}

The New York Convention (hereinafter The Convention) principally aims 
to prevent any discrimination against foreign and non-domestic awards. It obliges the parties to ensure such awards and to recognize general capability of enforcement in their jurisdiction in the same way as domestic awards. ${ }^{16}$ Almost all the major international trading nations are the parties to the Convention, ${ }^{17}$ including China, and Iran. Article I of the Convention provides:

This Convention shall apply to the recognition and enforcement of arbitral awards made in the territory of a State other than the State where the recognition and enforcement of such awards are sought, and arising out of differences between persons, whether physical or legal. It shall also apply to arbitral awards not considered as domestic awards in the State where their recognition and enforcement are sought. ${ }^{18}$

In accordance with the Convention, an award can be enforced in the country in which it was made. In this regard, the Convention also stipulates that these countries are allowed to invoke either one or both of two reservations referred to in Article I(3). The first so-called 'reciprocity' reservation limits recognition and enforcement of awards to those made in a Contracting State. ${ }^{19}$ The second socalled 'commercial' reservation limits recognition and enforcement to differences that are considered commercial under the domestic law of the forum in which enforcement is sought. ${ }^{20}$ In this case, China and Iran ratified the Convention with both reservations. ${ }^{21}$

As Contracting States, they are required to "recognize the awards as binding" and to enforce the awards according to the State's own rules of procedure pursuant to Article III of the Convention. A State may not impose "more onerous conditions or higher fees or charges" for the recognition or enforcement of awards under the Convention than it would impose for a domestic award. ${ }^{22}$ Further, the procedure for acquiring enforcement of an award is straightforward under Article IV of the Convention. The party seeking enforcement must supply the court with a "duly authenticated original award" and either the original or certified copies of the arbitration agreement. ${ }^{23}$ The continued strength of the Convention lies in Article $\mathrm{V}$, which recognizes only seven grounds for refusing enforcement of an arbitral award. ${ }^{24}$ A party hoping to block the enforcement of an award should bear the burden of proving that one of the seven grounds for refusing enforcement exists. ${ }^{25}$ 


\section{Case Studies: Implementation of the New York Convention}

\section{A. China}

Recognition and Enforcement of Foreign Awards in China

China acceded to the New York Convention on January 22, 1987. ${ }^{26}$ When signing the Convention, China made a 'reciprocity' and 'commercial' reservation to its membership. ${ }^{27}$ In 1987, the Supreme People's Court issued a Circular on the Implementation of the Convention on the Recognition and Enforcement of Foreign Arbitral Awards Entered by China (hereinafter SPC's Circular) as the implementing regulation succeeding China's accession to the Convention. The SPC's Circular expressly stipulates that China will recognize and enforce awards made in other contracting states, which is also in line with Article 282 of the Civil Procedure Law of the People's Republic of China 2012 (hereinafter PRC Civil Procedure Law) based on the principle of reciprocity. ${ }^{28}$ It goes on providing that where there is any conflict between the provisions of the Convention and those of the PRC Civil Procedure Law, the Convention shall prevail. ${ }^{29}$

Article 4 of the SPC's Circular afterward describes that Chinese courts should enforce a Convention award if none of the grounds for refusing enforcement as set out in Article 5(1) and (2) of the Convention apply. In the case of nonconvention awards, Chinese courts would not recognize a foreign award from a non-contracting state unless a treaty to which China is a signatory requires recognition, or the other country recognizes and enforces the CIETAC arbitration awards. $^{30}$

As regard the commercial reservation, the provisions of the Convention are applied only to disputes arising from legal relationships, whether contractual or not, which are considered 'commercial' under Chinese law. According to Article 2 of the SPC's Circular, "Contractual and Non-Contractual Commercial Legal Relationship" specifically refers to the economic rights and obligations resulted from contract, infringement or arising from law, such as sale of goods, lease of property, project contracting, processing, technology assignment, joint adventure, joint business operation, exploration and development of natural resources, insurance, credit, labor service, surrogate, consultation service, marine / civil aviation / railway / road passenger and cargo transportation, product liability, environment pollution, marine accident, dispute over ownership, etc. However, it 
does not include the dispute between foreign investors and the host government. Accordingly, another form of disputes, falling beyond the scope of this Article, is not within Chinese jurisdiction.

Meanwhile, arbitration in China is primarily governed by Arbitration Law of the People's Republic of China (hereinafter PRC Arbitration Law). ${ }^{31}$ The provisions of the PRC Arbitration Law are apparently inconsistent with those of the PRC Civil Procedure Law. For example, Articles 70 and 71 of the PRC Arbitration Law refer to Article 260 of the PRC Civil Procedure Law to indicate the grounds for which the award can be set aside or unenforceable, while the Article of 260 of the PRC Civil Procedure Law (2012 Amendments) no longer regulates the grounds to set aside the award. The grounds to reject the application of award enforcement are stipulated in Article 282 of the PRC Civil Procedure Law.

The aforementioned circumstance subtly shows that even if China has shown its commitment to assure legal certainty of foreign award enforcement by joining the Convention, China has not yet maintained consistency within the domestic laws to which the Convention will refer in enforcing foreign awards. If the government in the future can neither agilely update the legislations nor provide clear legal procedure to carry out the Convention's mandates, it will come across legal uncertainty to the enforcement of foreign awards. Due to limited online resource making it more arduous to be verified, the Convention consequently would have had little effect. Therefore, to the case at hand, the upto-date Chinese legislations are urgently needed as the implementing rules to the Convention in order to support future recognition and enforcement of foreign awards in China.

\section{Conditions for Recognition and Enforcement}

The Chinese government has long adhered to the principle that foreign awards would be recognized and enforced under certain conditions ${ }^{32}$ as stipulated in Article 282 of the PRC Civil Procedure Law. Ren Jianxin, the Former President of the PRC Supreme People's Court and was then Deputy Head of China Council for the Promotion of International Trade further asserted: 
is in fact fully secured so long as [the awards] are fair and not in violation of the Chinese laws and policies. There are also provisions in some bilateral treaties and agreements ... guaranteeing the enforcement of arbitral awards on a reciprocal basis. In fact, Chinese corporations and enterprises will execute foreign awards voluntarily. $^{33}$

This passage summarizes the necessary conditions for recognition and enforcement of foreign awards, as well as China's claim of voluntary compliance to such recognition and enforcement. ${ }^{34}$ Under these conditions, foreign awards could be fairly enforced, consonant with Chinese laws, and consistent with Chinese policies ${ }^{35}$ for the internationally commonplace requirement of reciprocity. ${ }^{36}$

\section{Iran}

Recognition and Enforcement of Awards in Iran

Iran acceded to the New York Convention on October 15, 2001 with both commercial and reciprocity reservations. ${ }^{37}$ It means that Iran will apply the Convention the commercial disputes whether contractual or non-contractual and the awards issued in another Contracting State. ${ }^{38}$ Before its accession, Iran had adopted the Law on International Commercial Arbitration ("LICA"), applying to international arbitrations. ${ }^{39}$ Iranian authorities claim that the LICA closely follows the UNCITRAL Model Law (hereinafter Model Law) so that similarities would undoubtedly exist between the two rules both structurally and substantively. ${ }^{40}$

As suggested in the Model Law, the term 'commercial' is broadly defined to include "the sale and purchase of goods and service, transportation, insurance, financial matters, consulting services, investment, technical cooperation, representation, commission agency, contract work and other similar activities." ${ }^{41}$ Accordingly, it provides more flexibility for foreign investors or lawyers to establish the subject matter jurisdiction under the LICA.

To enforce foreign awards, it is first necessary to differentiate between domestic and foreign (international) awards. In other words, the nationality of the award should be firstly determined. Article 1 of the Model Law explains that an arbitration is considered 'international' if place of business of the parties is in different states at the time of conclusion of the arbitration agreement; if the 
place of arbitration is in a different state than the parties' states; or if the place of performance of the subject matter of the agreement is in a third state. Meanwhile, Article 1(b) of the LICA explicates that arbitration is considered 'international' when one of the parties at the time of conclusion of the arbitration agreement is not 'Iranian' under the laws of Iran. Article 1(b), as the domestic law of Iran for adopting the Model Law, has taken a different approach in comparison with the Model Law; it has not reckoned the seat of arbitration as relevant element for recognition of the arbitration as 'international' or 'foreign.' Article 2(1) of the LICA also provides another condition to consider arbitration award as 'foreign.' In this case, the dispute should have been raised with respect to "international commercial relations" of parties.

Aforesaid facts elucidate that the subject matter of arbitration and disputing parties would take significant role for recognizing the award as 'international.' Correspondingly, if a dispute arises between two Iranians whose place of business is not Iran or if one of the parties holds double nationalities, their dispute does not qualify as 'international' under the LICA. ${ }^{42}$ If the award is considered domestic under Iranian Law, the Convention shall not apply ${ }^{43}$ so that the award could not be requested to be enforceable in Iran under the Convention.

\section{Grounds for Setting Aside and Refusal of Enforcement of Awards}

Article 33(1) of the LICA contains the same grounds for both the setting aside and refusal of enforcement of arbitral awards. When any of them will lead to the annulment or refusal of enforcement of the award, the following grounds must be invoked by the party seeking annulment or resisting enforcement of the award:

\footnotetext{
a. A party to the arbitration agreement was under some incapacity;

b. The arbitration agreement is not valid under the law to which the parties have subjected it or failing any indication thereon, under the Iranian law;

c. The provisions of the LICA concerning the proper notice of the appointment of an arbitrator or arbitration request are not observed;

d. The party resisting enforcement or seeking annulment of the award was - due to reasons beyond his control - unable to present his case;

e. The arbitrator rendered an award beyond the scope of his authority. Should the decisions on matters submitted to arbitration be separated from those not so submitted, only that part of the award which contains decisions on matters not submitted to arbitration will be set aside or refused enforcement;
} 
f. The composition of the arbitral tribunal or the arbitral procedure was not in accordance with the agreement of the parties and/or in the silence of or failing such agreement, was not in accordance with the LICA;

g. The arbitration award includes the affirmative view of the arbitrator whose replacement has been accepted by the court located in the provincial capital where the seat of arbitration is located;

h. If the award of the arbitral tribunal relies on a document which, according to a final judgment, was falsified; and

i. A document is found, after the issuance of the award, proving the rightfulness of the party resisting enforcement or seeking annulment of the award and which is proven to have been or caused to have been concealed by the other party.

Additionally, Article 34 of the LICA stipulates the following grounds, when any of which will lead to the annulment or refusal of enforcement of the award, must be raised ex-officio by the judge:

1. The subject matter of the dispute is not capable of settlement by arbitration under Iranian law;

2. The award is in conflict with the Iranian public policy or good morals and/or the mandatory provisions of the LICA;

3. The arbitral tribunal's award with respect to immovable properties located in Iran is in contradiction with laws of Iran and/or valid notarial documents, unless the arbitral tribunal has the authority to compromise in the case of the latter.

\section{Conclusion}

In this paper, the enforcement of foreign awards China and Iran has been examined by comparing arbitration laws of both countries. Although taking distinctive approaches in enforcing foreign award, they are basically considering similar grounds for refusing the enforcement of foreign award. Nonetheless, the problem would often arise when analyzing foreign award enforcement mainly due to the absence of clear, comprehensive, and well-ordered domestic law in regulating such recognition and enforcement. In particular, the inconsistency among international and domestic rules are often found; for example, secondary law relating to the primary law has not yet been amended, even when the primary law has been adjusted. This matter will lead to misperception or confusion or the 
worst case, legal uncertainty when foreign lawyers examine the domestic laws relating to foreign award enforcement. It is therefore imperative for a state to ensure that the national laws are up-to-date and inclusive, and the existence of ample resources to support the interpretation of the law.

\section{REFERENCES}

1. See generally V. Elisseeff, The Silk Roads: Highways of Culture and Commerce (2001).

2. UNESCO, Countries alongside the Silk Road Routes, available at http://en.unesco.org/ silkroad/countries-alongside-silk-road-routes (last visited on Feb. 8, 2018).

3. CLSA, A Brilliant Plan: One Belt, One Road, available at https:/www.clsa.com/special/ onebeltoneroad (last visited on Feb. 8, 2018).

4. Id.

5. G. Cameron III, International Business Law: Cases and Materials ch. 1 (2015).

6. Id.

7. J. McLaughlin, Arbitration and Developing Countries, 13 INT'L LAw. 211 (1979), available at https://www.jstor.org/stable/pdf/40705956.pdf (last visited on Feb. 8, 2018).

8. O. Ozumba, Enforcement of Arbitral Awards: Does the Public Policy Exception Create Inconsistency?, C. E. P. M. L. P. Annual Rev. (2010).

9. M. Saunders \& C. Solomon, Enforcement of Arbitral Awards against States and State Entities, 23 ARB. INT'L 467 (2014), available at https://academic.oup.com/arbitration/articleabstract/23/3/467/259418? redirectedFrom=PDF (last visited on Feb. 8, 2018).

10. G. Born, International Civil Litigation in The United States Courts: Commentary \& Materials 1040 (3d ed. 1996).

11. Saunders \& Solomon, supra note 9.

12. Ozumba, supra note 8.

13. Born, supra note 10.

14. Id.

15. UN, Convention on the Recognition and Enforcement of Foreign Arbitral Awards 2015, available at $\mathrm{http}: / / \mathrm{www}$.uncitral.org/pdf/english/texts/arbitration/NY-conv/New-YorkConvention-E.pdf (last visited on Feb. 8, 2018).

16. Id.

17. P. Sanders, A Twenty Years' Review of the Convention on the Recognition and Enforcement of Foreign Arbitral Awards, 13 InT'L Law. 269 (1979), available at https://www.jstor.org/ stable/40705960 (last visited on Feb. 8, 2018).

18. The New York Convention on the Recognition and Enforcement of Foreign Arbitral Awards 1958, art. I(1). For details, see H. Harnik, Recognition and Enforcement of Foreign Arbitral 
Awards, 31 Ам. J. Cомp. L. 705(1983).

19. Id.

20. Id.

21. UN, Contracting States, the official website of the New York Arbitration Convention available at http://www.newyorkconvention.org/countries (last visited on Feb. 8, 2018).

22. New York Convention, art. III.

23. Id. art. IV.

24. J. McLaughlin \& L. Genevro, Enforcement of Arbitral Awards under the New York Convention-Practice in U.S. Courts, 3 Berkeley J. InT'L L. 253 (1986), available at https:// scholarship.law.berkeley.edu/cgi/viewcontent.cgi?article=1034\&context=bjil (last visited on Feb. 8, 2018).

25. A. Van Den Berg, The New York Arbitration Convention of 1958: Towards A Uniform Judicial INTERPRETATION 9 (1994).

26. UN, supra note 21.

27. M. Moser \& T. Cheng, Hong Kong Arbitration: A User’s Guide (2014).

28. Circular of Supreme People's Court ("SPC") on the Implementing Convention on the Recognition and Enforcement of Foreign Arbitral Awards Entered by China, art. 1.

29. Id. See also The Second Amendment of PRC Civil Procedure Law 2012, art. 260.

30. G. Alexander Lourie, International Commercial Arbitration in China: History, New Development and Current Practice, 28 J. Marshall L. Rev. 539 (1994-5).

31. G. Pisacane, L. Murphy \& C. Zhang, Arbitration in China: Rules \& Perspective 1 (2016).

32. Supra note 27 , at 123.

33. Id.

34. Id.

35. PRC Civil Procedure Law art. 282.

36. Supra note 27, at 124.

37. UN, supra note 21.

38. New York Convention art. I (3).

39. H. Gharavi, Update, Thoughts and Perspectives on Iran's International Arbitration Regime, 4 Swiss Arb. Bull. 723 (2000).

40. H. Gharavi, The 1997 Iranian International Commercial Arbitration Law: The UNCITRAL Model Law, 15 InT'L ARB. 1 (1999), available at https://academic.oup.com/arbitration/ article-abstract/15/1/85/294717?redirectedFrom=PDF (last visited on Feb. 8, 2018).

41. Law on International Commercial Arbitration, art. 2.

42. A Iranshahi, Cross-border Effects of International Arbitration Awards, Legal ReSEARCH J.

Shahid Beheshty U. 239-90(Winter 2011) < available only in Persian>

43. New York Convention art. I(1). 